\title{
Microbial population analysis of the midgut of Melophagus ovinus via high-throughput sequencing
}

\author{
De-Yong Duan ${ }^{1,2}$, Guo-Hua Liu' ${ }^{1,2}$, Tian-Yin Cheng ${ }^{1,2^{*}}$ and Ya-Qin Wang ${ }^{1,2}$
}

\begin{abstract}
Background: Melophagus ovinus, one of the most common haematophagous ectoparasites of sheep, can cause anaemia and reductions in weight gain, wool growth and hide value. However, no information is available about the microfloral structure of the midgut of this ectoparasite. In the present study, we investigated the microbial community structure of the midgut contents of fully engorged female and male M. ovinus using Illumina HiSeq.

Results: The phylum showing the highest abundance was Proteobacteria (99.9\%). The dominant bacterial genera in females and males were Bartonella, Arsenophonus and Wolbachia. Some less abundant bacterial genera were also detected, including Enterobacter, Acinetobacter, Halomonas, Shewanella, Bacillus and Staphylococcus.

Conclusions: Bartonella, Arsenophonus and Wolbachia were the dominant bacterial genera in the midgut of female and male M. ovinus. Although detected, Enterobacter, Acinetobacter, Halomonas, Shewanella, Bacillus and Staphylococcus showed low abundances. Importantly, this is the first report of the presence of Arsenophonus, Wolbachia, Enterobacter, Halomonas, Shewanella, Bacillus and Staphylococcus in the midgut of M. ovinus.
\end{abstract}

Keywords: Microbial community structure, Midgut, Melophagus ovinus, Illumina HiSeq, 165 rDNA

\section{Background}

Melophagus ovinus, also termed the sheep ked, is a wingless fly that belongs to the order Diptera, family Hippoboscidae. Melophagus ovinus is one of the most common haematophagous ectoparasites of sheep [1] and is mainly found on the animal's neck, shoulder and perineal regions and between the hind legs. The life-cycle of $M$. ovinus includes four developmental stages: larva, pupa, nymph and adult, all of which occur in the wool of the host [2]. Although sheep are generally considered to be a definitive host of this ectoparasite, $M$. ovinus can also parasitize the body surfaces of goats [3], European bison [4], rabbits and humans [5] and red foxes [6]. The number of $M$. ovinus individuals within a flock varies significantly over the annual cycle, increasing on ewes throughout winter until the lambing season in March and $M$. ovinus and decreasing on adults while rapidly

\footnotetext{
* Correspondence: hn5368@163.com

${ }^{1}$ College of Veterinary Medicine, Hunan Agricultural University, Changsha, Hunan Province 410128, China

${ }^{2}$ Hunan Co-Innovation Center of Animal Production Safety, Changsha, Hunan Province 410128, China
}

(c) The Author(s). 2017 Open Access This article is distributed under the terms of the Creative Commons Attribution 4.0 International License (http://creativecommons.org/licenses/by/4.0/), which permits unrestricted use, distribution, and reproduction in any medium, provided you give appropriate credit to the original author(s) and the source, provide a link to the Creative Commons license, and indicate if changes were made. The Creative Commons Public Domain Dedication waiver (http://creativecommons.org/publicdomain/zero/1.0/) applies to the data made available in this article, unless otherwise stated.

\section{population reaches a minimum from April-May [7].}

The blood-feeding process of $M$. ovinus causes harm to the host in two ways. First, M. ovinus can cause pruritus and inflammation; as the host attempts to rub, scratch and bite the parasitized location, some wool will be lost, and the skin will also be damaged, leading to secondary microbial infections and establishing conditions for cutaneous myiasis [2, 7-10]. A large number of $M$. ovinus parasitizing a single sheep can result in anaemia and reductions in weight gain and wool growth [11] as well as hide value $[2,7,12]$.

Secondly, as a vector, M. ovinus can transmit Trypanosoma melophagium [12], Anaplasma ovis [13], Acinetobacter [2, 13] and Borrelia burgdorferi [14]. In addition, Luedke et al. [15] reported that $M$. ovinus can mechanically transmit blue-tongue virus, which causes a serious infectious disease in sheep. Recently, Rickettsia was also detected at a high prevalence $(12.63 \%, 12 / 95)$ in $M$. ovinus from Taklimakan Desert in China, and phylogenetic analysis confirmed the presence of $R$. raoultii and $R$. slovaca [8]. 
Some studies have reported negative results for vector-borne pathogens via molecular screening of $M$. ovinus. For example, Hubálek et al. [16] found that tickborne encephalitis virus and other arboviruses were not present in $M$. ovinus. Similarly, Nelder et al. [17] screened a $150 \mathrm{M}$. ovinus individuals for Coxiella burnetii, with negative results. Rudolf et al. [18] also failed to find evidence of flaviviruses, phleboviruses, bunyaviruses, Borrelia burgdorferi, Rickettsia spp., Anaplasma phagocytophilum or Babesia spp. in M. ovinus.

However, previous studies on $M$. ovinus, including those with positive or negative results, have focused on one specific pathogen, whereas a comprehensive study on bacteria associated with $M$. ovinus (including pathogenic and symbiotic bacteria) has yet to be conducted.

Illumina HiSeq is an expedient and efficient method for analysing microbial community structure, with the following advantages: (i) bacterial identification does not depend on bacterial culture, and (ii) these techniques can identify bacterial species present at low relative abundance, providing more precise microbial population information $[19,20]$. Investigation of the $16 \mathrm{~S}$ rDNA region can be used for species identification and as an index for microbial systematics, classification and identification. The V3-V4 hypervariable regions are the most accurate and can identify organisms at the genus level [21].

The aim of this study was to apply Illumina HiSeq based on the V3-V4 hypervariable regions of the $16 \mathrm{~S}$ rDNA region to examine the microbial community structure of the midgut of $M$. ovinus to determine which pathogenic and symbiotic bacteria were carried by $M$. ovinus. The findings may lead to a strategy for preventing infestations of $M$. ovinus and vector-borne pathogens.

\section{Methods}

\section{Sample collection and DNA extraction}

All of the $M$. ovinus individuals used in this study were obtained from sheep bred in the city of Jiuquan in Gansu Province (1500 m above sea level; 39 $71^{\prime} \mathrm{N}, 98^{\circ}$ 50 'E), China, in October 2016. The samples of M. ovinus were removed using forceps from wool at the neck, shoulder and perineal region and between the hind legs (the sheep were all bred by the same farmer and had same environment). The $M$. ovinus samples were immediately transported to the Laboratory of Molecular Physiology of the College of Veterinary Medicine, Hunan Agricultural University. Five adult females (fully engorged) and 5 adult males (fully engorged) M. ovinus were examined in this study. All $M$. ovinus specimens were processed as individual samples. DNA extraction procedures were performed in a biosafety cabinet to ensure protection of the samples from environmental contamination. First, the $M$. ovinus samples were washed three times in $70 \%$ ethanol for $2 \mathrm{~min}$, followed by a wash with sterile deionized water to remove environmental debris and to disinfect the surface. The M. ovinus individuals were stabilized with fine-tipped forceps by holding their rear portions; the forceps were inserted into the rear of each $M$. ovinus, and the dorsum was sliced to expose the organs. The midgut was removed, and the contents were extruded and suspended in $0.01 \mathrm{M}$ phosphate-buffered saline ( $\mathrm{PBS}, \mathrm{pH} 7.3$, including $\mathrm{NaCl}, \mathrm{KCl}, \mathrm{KH}_{2} \mathrm{PO}_{4}$ and $\mathrm{Na}_{2} \mathrm{HPO}_{4} \cdot 12 \mathrm{H}_{2} \mathrm{O}$ ). The contents were then centrifuged at $300 \mathrm{r} / \mathrm{min}$ for $5 \mathrm{~min}$, and the supernatant was retained. A $1 \mathrm{ml}$ aliquot of the supernatant was centrifuged at 10,000 r/min for $1 \mathrm{~min}$, the precipitates were subjected to DNA extraction using a TIANamp Bacteria DNA kit (TianGen Biotech Corporation, Beijing, China) according to the manufacturer's protocol. The DNA concentration was determined by $1 \%$ agarose gels electrophoresis. The DNA samples were diluted to a concentration of $1 \mathrm{ng} / \mu \mathrm{l}$ using sterile water and stored at $-20{ }^{\circ} \mathrm{C}$ until analysis.

\section{Sequencing \\ Amplicon generation}

The primers 341F (5'-CCT AYG GGR BGC ASC AG-3') and 806R (5'-GGA CTA CNN GGG TAT CTA AT-3') with sample-identifying barcodes were used to amplify the V3-V4 hypervariable regions of the bacterial 16S rDNA.

A polymerase chain reaction (PCR) mixture $(20 \mu \mathrm{l}$ per reaction) was prepared with $15 \mu$ l Phusion ${ }^{\circledR}$ High-Fidelity PCR Master Mix (New England BioLabs, Ipswich, USA), $0.2 \mu \mathrm{M}$ forward and reverse primers, and $10 \mathrm{ng}$ template DNA. The reaction was as follows: initial denaturation at $98{ }^{\circ} \mathrm{C}$ for $1 \mathrm{~min}$, followed by 30 cycles of $98{ }^{\circ} \mathrm{C}$ for $10 \mathrm{~s}, 50{ }^{\circ} \mathrm{C}$ for $30 \mathrm{~s}$ and $72{ }^{\circ} \mathrm{C}$ for $60 \mathrm{~s}$, and a final elongation at $72{ }^{\circ} \mathrm{C}$ for $5 \mathrm{~min}$. A negative control (sterile water) was included with each reaction. The PCR products were stored at $4{ }^{\circ} \mathrm{C}$ overnight or were frozen until use.

\section{PCR product quantification and qualification}

The PCR products (with $5 \mu \mathrm{l}$ of $1 \times$ gel loading buffer) were subjected to $2 \%$ agarose gel electrophoresis at $70 \mathrm{~V}$ for $50 \mathrm{~min}$; each sample separated by an empty well. The bands were excised (the expected size was between 200 and 250 bp) using a clean scalpel, weighed, and extracted and purified using a GeneJET Gel Extraction Kit (Thermo Fisher Scientific, Waltham, USA). Each PCR product was quantified, and dilutions were performed to obtain a stock solution at $1 \mu \mathrm{g} / \mathrm{ml}$.

\section{Library preparation and sequencing}

Sequencing libraries were generated using a TruSeq ${ }^{\odot}$ DNA PCR-Free Sample Preparation Kit (Illumina, San 
Diago, USA) following the manufacturer's protocol; index codes were added. The library quality was assessed using a Qubit @ 2.0 Fluorometer (Thermo Fisher Scientific) and quantitative PCR (Q-PCR). The libraries were sequenced on the Illumina HiSeq platform, and 250 bp paired-end reads were generated.

\section{Data analysis}

Paired-end reads with unique barcodes were trimmed to remove the barcodes and primers. To obtain raw tags, the trimmed reads were assembled using the FLASH software package (Version 1.2.7) [22]. This program was used to merge the paired-end reads when at least some overlapped with the reads produced by the same DNA fragment's opposite end. Raw tags were analysed using QIIME software (Version 1.7.0) [23] under specific filtering conditions to obtain high-quality clean tags (effective tags). Additionally, chimeric sequences were removed using the UCHIME algorithm (http://www.drive5.com/ usearch/manual/uchime_algo.html), comparing the tags to Unite Reference Database (https://unite.ut.ee/) to detect chimeric sequences; effective tags were ultimately obtained. Uparse software (Version 7.0.1001) [24] was used to cluster the sequences with $97 \%$ similarity into operational taxonomic units (OTUs).

A representative sequence for each OTU was screened for further annotation. The taxonomy of the OTUs was obtained using QIIME software (Version 1.7.0) against Unite Database (https://unite.ut.ee/). MUSCLE software (Version 3.8.31) [25] was used to derive the phylogenetic relationships among OTUs via multiple sequence alignment. Alpha and beta diversities were calculated based on normalized OTU abundance information, which was obtained using the sample with the fewest sequences as a standard. Indices, including observed species, Shannon's diversity index and Simpson's diversity index and
Good's coverage, were calculated with QIIME (Version 1.7.0), and the results are displayed using $\mathrm{R}$ software (Version 2.15.3).

\section{Results}

Morphological characteristics of Melophagus ovinus

Melophagus ovinus is an entirely wingless brown fly (Dipteran: Hippoboscidae). Both sexes have three pairs of legs, and the tibial ends have large claws that enable M. ovinus to maintain its position in the sheep's fleece (Figs. 1a, 2a). The insect has piercing-sucking mouthparts, reduced compound eyes and antennae. Body length ranges from approximately 4.0 to $6.2 \mathrm{~mm}$; the body wall is leathery, and the entire surface exhibits dense setae. The head is short and embedded in the chest; the abdomen is wide and ameristic, with an oval or round shape. The M. ovinus abdomen differs depending on the sex: the female's abdomen is large, round, and invaginated on the back (Fig. 1b), whereas the male's abdomen is small, round, and embossed on the back (Fig. 2b).

\section{General statistics}

Sequencing of the amplicons of the V3-V4 hypervariable regions of the bacterial $16 \mathrm{~S}$ rDNA produced a number of reads for the female and male $M$. ovinus samples evaluated. A total of 145,679 sequences were obtained after barcodes and primer sequences were trimmed, and following quality control, 124,707 high-quality, effective tags were generated for analysis using OTU selection and taxonomic assignments.

The alpha diversity indices of the bacterial communities of female and male M. ovinus are shown in Table 1. Shannon's diversity index and Simpson's diversity index were similar for the female and male samples, suggesting that fully engorged females and males have similar
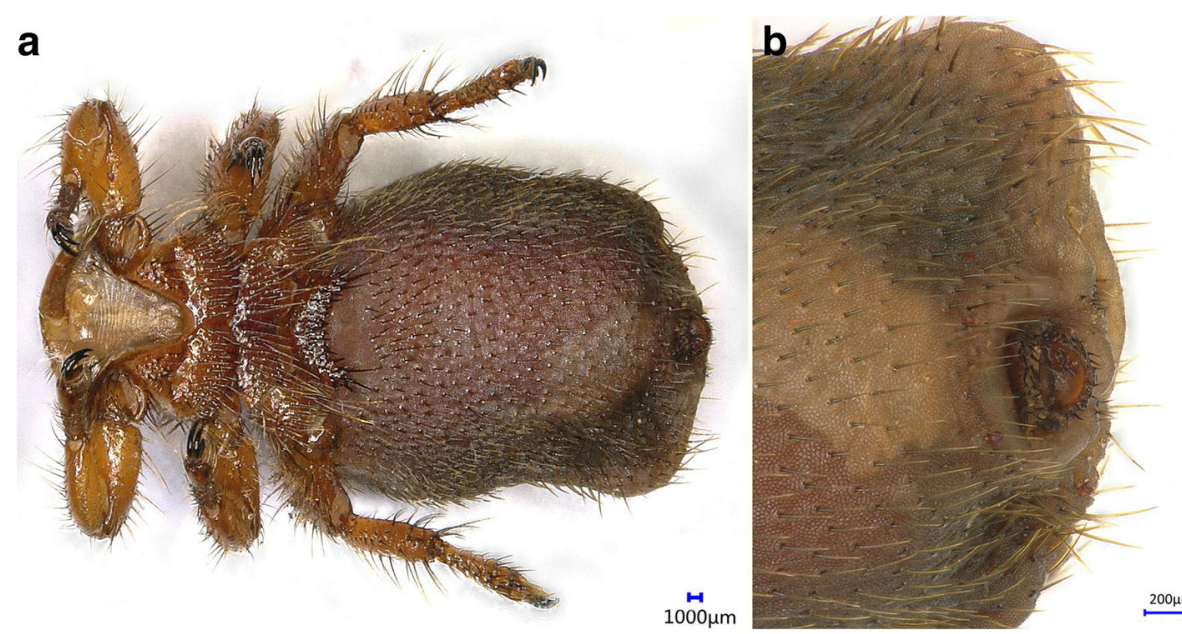

Fig. 1 Photomicrographs of female Melophagus ovinus. a Ventral view of the female. b Posterior end of the female 

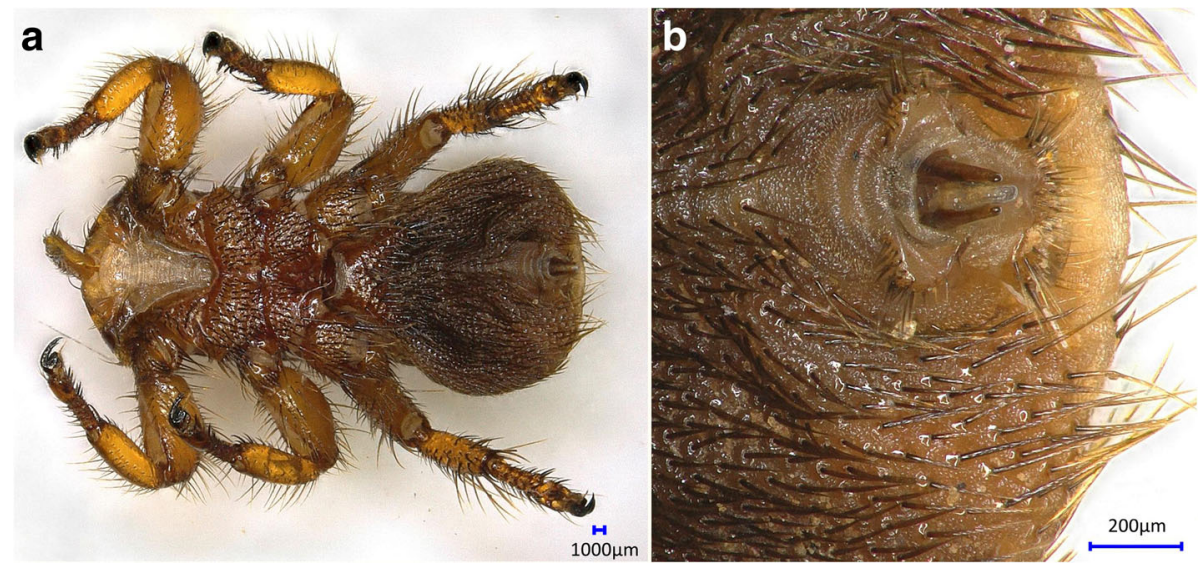

Fig. 2 Photomicrographs of male Melophagus ovinus. a Ventral view of the male. $\mathbf{b}$ Posterior end of the male

bacterial community distributions. Good's coverage rates of all samples were $100 \%$, indicating that the sequencing depths were sufficient to saturate the bacterial diversity, with the majority of bacteria in the two samples being previously described.

OTU cluster analysis is shown as a Venn diagram in Fig. 3. Nine and 8 OTUs were obtained for female and male M. ovinus, respectively. Seven of the OTUs showed high similarity between the two groups, indicating that fully engorged females and males have similar microbial populations.

In all samples, the majority of tags were classified, and more than $99 \%$ of tags were assigned to a genus. Only a small fraction of tags could be classified at the species level.

\section{Microbial population characteristics}

Proteobacteria and Firmicutes were the main bacterial phyla in fully engorged female and male $M$. ovinus. Proteobacteria comprised $99.9 \%$ of the OTUs in the two groups, showing a marked predominance. The microbial population characteristics at the genus level are shown in Table 2. Bartonella, Arsenophonus, Wolbachia, Enterobacter, Acinetobacter, Halomonas, Shewanella, Bacillus and Staphylococcus were detected in all samples, with Bartonella, Arsenophonus and Wolbachia predominating. Although Enterobacter, Acinetobacter, Halomonas, Shewanella, Bacillus and Staphylococcus were detected, abundance for these taxa was low. Arsenophonus and Wolbachia were abundant in females (55.69 and
$3.34 \%$, respectively) but were less abundant in males (38.14 and $1.67 \%$, respectively). In contrast, Bartonella was more abundant in males $(59.91 \%)$ than in females (40.56\%), though the number of samples was limited. Some of the bacterial genera appeared to show a sexbased selectivity, as they were only present in one sex. For example, Novosphingobium was exclusively found in females, whereas Salinicoccus was only detected in males, both with low abundance. At the species level, only Pseudomonas aeruginosa, Shewanella algae and Staphylococcus xylosus were identified, all of which were detected in both fully engorged females and males.

\section{Discussion}

Microbial community structures in the midgut of fully engorged female and male $M$. ovinus were investigated using Illumina HiSeq high-throughput sequencing. Our results showed certain bacterial genera that had already been reported in previous studies of $M$. ovinus, such as Bartonella and Acinetobacter, and we also detected bacterial genera that have not yet been reported in M. ovinus, including Arsenophonus, Wolbachia, Enterobacter, Halomonas, Shewanella, Bacillus and Staphylococcus.

Bartonella is a Gram-negative, haemotropic, fastidious, aerobic bacterium capable of intracellular parasitism [26]. Pathogenic Bartonella can cause many diseases, including Salonica fever, cat-scratch fever, and Carrin's disease. Bartonella has a wide range of parasitic hosts and can infect humans and a variety of other vertebrates [27]. The main vectors are blood-sucking parasitic

Table 1 Indices of bacterial abundance and diversity in samples

\begin{tabular}{lllll}
\hline Sample & No. of species observed & Shannon's index & Simpson's index & Good's coverage \\
\hline Female & 9 & 1.199 & 0.524 & 1 \\
Male & 8 & 1.098 & 0.495 & 1
\end{tabular}

The Shannon's diversity index and Simpson's diversity index were used to estimate the total number of species in the community. Observed species was the number of species observed in a sample. Good's coverage index was used to estimate the percentage of total bacterial OTUs represented in a sample 


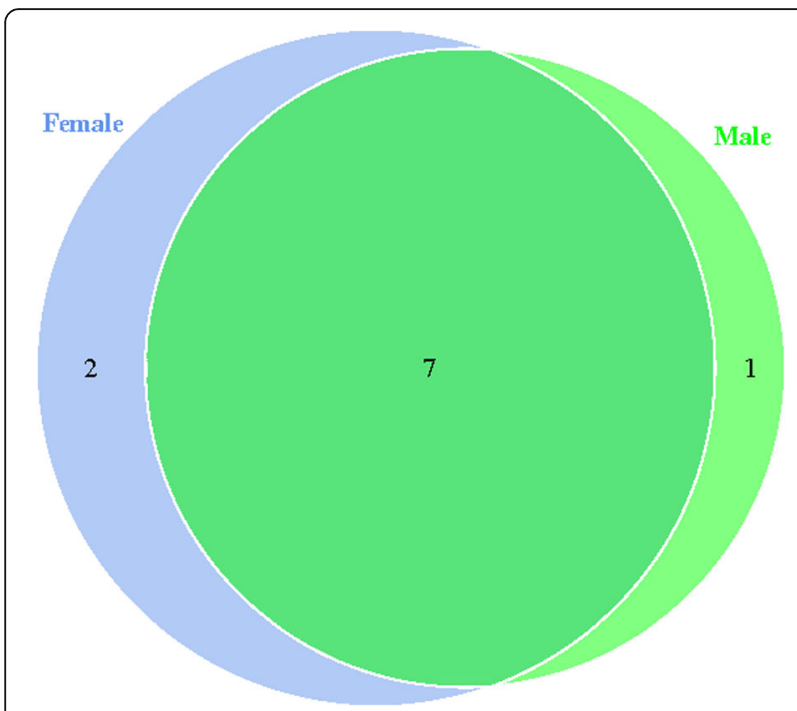

Fig. 3 Venn diagrams of two midgut content samples based on OTUS

arthropods, such as lice, chiggers [28] and ticks [29], and mammals are the main reservoir hosts. When Bartonella infect a host, the bacteria first proliferate in endothelial cells and are later released into the blood, thereby infecting erythrocytes. When a haematophagous arthropod feeds on an infected host, Bartonella bacteria enter the vector, which then bites a healthy host, transferring the bacteria to the new host via the saliva and causing disease [28]. In the present study, we found a higher abundance of Bartonella in the midgut of M. ovinus than other relatively common bacterial genera, with males (59.91\%) showing higher levels than females (40.56\%). This finding suggests that M. ovinus can harbour a mass of Bartonella, which can adapt well to the midgut of this insect.

Arsenophonus, an intracellular symbiotic bacterium with a wide range of hosts and a high degree of biological diversity [30], was also present in the $M$. ovinus midgut, with females (55.69\%) having higher levels than males (38.14\%). Duron et al. [31] examined Arsenophonus $16 \mathrm{~S}$ rDNA in 136 species of wild arthropods and found six species to be infected. Arsenophonus, which is extensively and non-specifically distributed in different tissues and organs of host insects, plays an important role in killing male hosts, allowing female hosts to obtain more resources and reduce adverse impacts due to inbreeding within the population. Gherna et al. [32] discovered that when Nasonia vitripennis become infected with Arsenophonus, approximately 80\% of male progeny die; this phenomenon can result in a preference for female hosts. In previous studies, Arsenophonus was demonstrated to provide vitamins and other nutrients to host insects [33]. However, further research is required to determine whether the high abundance of Arsenophonus in the midgut of M. ovinus is related to nutrient provision.

Wolbachia is a cytoplasmically inherited intracellular symbiotic bacterium that can cause changes in a host's reproductive behaviour $[34,35]$. Wolbachia naturally infects a wide range of hosts, including nematodes [36], crustaceans and mites [37, 38] and dipteral insects [39]. According to a previous report, $60 \%$ of terrestrial insect species are infected with Wolbachia [40], which exists mainly in the ovaries and spermaries of insect hosts. In the ovary, Wolbachia mainly affects trophoblast cells, which participate in oogenesis as nutrient carriers. Wolbachia can induce reproductive manipulation of cytoplasmic incompatibility and parthenogenesis in the process of transport, thus regulating reproductive behaviour [41]. These bacteria are also found in other tissues, for instance, in the head, chest, midgut, Malpighian tubules and blood lymph tissues of adult Drosophila [42]. In the present investigation, we identified Wolbachia in the midgut of $M$. ovinus, with females (3.34\%) exhibiting higher levels than males (1.67\%).

Acinetobacter is a Gram-negative, obligate aerobic coccobacillus present in the normal flora of humans and animals and is widely distributed in natural environments (i.e. water, soil, mud, living organisms and vegetables) [43-46]. An opportunistic pathogenic bacterium, Acinetobacter frequently causes various types of infections, especially in immunocompromised individuals and in patients in intensive health care units. Acinetobacter has been detected in ticks and many types of arthropods. Kumsa et al. [47] performed molecular detection of Acinetobacter species in lice and M. ovinus from domestic animals in Oromia Regional State and found Acinetobacter lwoffii and a new Acinetobacter spp. (Acinetobacter sp. G13) in M. ovinus from sheep. In the

Table 2 The relative abundances of bacteria at the genus level in Melophagus ovinus. "Other" indicates the sum of relative genus abundance for the genera excluding the top 11

\begin{tabular}{|c|c|c|c|c|c|c|c|c|c|c|c|c|}
\hline \multirow[t]{2}{*}{ Sample } & \multicolumn{12}{|c|}{ Relative abundance (\%) } \\
\hline & Bar & $\mathrm{Ar}$ & Wo & En & $A C$ & $\mathrm{Ha}$ & Sh & St & $\mathrm{Bac}$ & No & Sa & Other \\
\hline Female & 40.56 & 55.69 & 3.34 & 0.28 & 0.084 & 0.013 & 0.008 & 0.008 & 0.003 & 0.002 & 0 & 0.012 \\
\hline Male & 59.91 & 38.14 & 1.67 & 0.2 & 0.055 & 0.006 & 0.008 & 0.002 & 0.003 & 0 & 0.003 & 0.003 \\
\hline
\end{tabular}

Abbreviations: Bar Bartonella, Ar Arsenophonus, Wo Wolbachia, En Enterobacter, Ac Acinetobacter, Ha Halomonas, Sh Shewanella, St Staphylococcus, Bac Bacillus, No Novosphingobium, Sa Salinicoccus 
present study, Acinetobacter was found in high abundance in the midgut of $M$. ovinus, though we could not identify the species.

Rickettsia is an obligate, intracellular, parasitic bacterium that is transmitted mainly through arthropods. In previous studies, Rickettsia was detected in M. ovinus collected in Hungary, with a prevalence of $1.67 \%(1 / 60)$ [13]. Recently, high prevalence rates $(12.63 \%, 12 / 95)$ for $R$. raoultii and $R$. slovaca were reported for M. ovinus from Taklimakan Desert in China [8]. However, two studies reported a failure to detect Rickettsia spp. in M. ovinus collected in Ethiopia and the Czech Republic [18, 47]. Using next-generation sequencing, we similarly were unable to detect Rickettsia in two groups of M. ovinus collected from Jiuquan in Gansu Province, China. This finding suggests that the capacity of M. ovinus to carry Rickettsia may depend on the geographical region.

\section{Conclusions}

Bartonella, Arsenophonus and Wolbachia were dominant bacterial genera in the midgut of fully engorged female and male M. ovinus. Although detected, Enterobacter, Acinetobacter, Halomonas, Shewanella, Bacillus and Staphylococcus showed low abundances. Importantly, this is the first report of Arsenophonus, Wolbachia, Enterobacter, Halomonas, Shewanella, Bacillus and Staphylococcus in the midgut of M. ovinus.

\section{Abbreviations}

OTUs: Operational taxonomic units

\section{Acknowledgements}

Not applicable.

\section{Funding}

This research was financially supported by a grant from the National Natural Science Foundation of China (No. 31372431), the Youth Science Foundation of Orient Science and Technology College of Hunan Agricultural University (No. 16QNZ13).

\section{Availability of data and materials}

The raw tags have been deposited in Sequence Read Archive (SRA) of NCB under BioProject accession number PRJNA381251. The individual run files received the accession numbers SRR5417208 and SRR5417209.

\section{Authors' contributions}

DDY and CTY conceived and designed the study. DDY performed the laboratory analyses and wrote the manuscript. DDY, LGH and WYQ critically revised the manuscript. All authors read and approved the final manuscript.

\section{Ethics approval}

This study was approved by the Animal Ethics Committee of Hunan Agricultural University (No. 43321503).

\section{Consent for publication}

Not applicable.

\section{Competing interests}

The authors declare that they have no competing interests.

\section{Publisher's Note}

Springer Nature remains neutral with regard to jurisdictional claims in published maps and institutional affiliations.

Received: 18 May 2017 Accepted: 3 August 2017

Published online: 09 August 2017

\section{References}

1. Gibson W, Pilkington JG, Pemberton JM. Trypanosoma melophagium from the sheep ked Melophagus ovinus on the island of St Kilda. Parasitology. 2010:137:1799-804.

2. Kumsa B, Parola P, Raoult D, Socolovschi C. Bartonella melophagi in Melophagus ovinus (sheep ked) collected from sheep in northern Oromia, Ethiopia. Comp Immunol Microbiol Infect Dis. 2014;37:69-76.

3. Bequaert J. A monograph of the Melophaginae, or ked-flies, of sheep, goats, deer and antelopes (Diptera, Hippoboscidae). Entomol Am. 1942;22:1-220.

4. Izdebska JN. European bison arthropod parasites from closed polish breeding facilities. Acta Parasitol. 2001;46:135-7.

5. Tetley JH. The sheep ked, Melophagus ovinus L. I Dissemination potential. Parasitology. 1958;48:353-63.

6. Lassnig H, Prosl H, Hinterdorfer F. Parasites of the red fox (Vulpes vulpes) in Styria. Wien Tierarztl Monat. 1998:85:116-22.

7. Small RW. A review of Melophagus ovinus (L.), the sheep ked. Vet Parasitol. 2005;130:141-55.

8. Liu D, Wang YZ, Zhang H, Liu ZQ, Wureli HZ, Wang SW, et al. First report of Rickettsia raoultii and $R$. slovaca in Melophagus ovinus, the sheep ked. Parasit Vectors. 2016;9:600.

9. Soulsby EJL. Helminths, arthropods and protozoa of domesticated animals. Seventh ed. Philadelphia: Lea and Febiger; 1982

10. Soulsby EJL. Helminths, arthropods and protozoa of domesticated animals (sixth edition of Mönnig's Veterinary Helminthology and Entomology). Can Vet J. 1969;10:223

11. Nelson WA, Slen SB. Weight gains and wool growth in sheep infested with the sheep ked Melophagus ovinus. Exp Parasitol. 1968;22:223-6.

12. Martinkovic F, Matanovic K, Rodrigues AC, Garcia HA, Teixeira MM. Trypanosoma (Megatrypanum) melophagium in the sheep ked Melophagus ovinus from organic farms in Croatia: phylogenetic inferences support restriction to sheep and sheep keds and close relationship with Trypanosomes from other ruminant species. J Eukaryot Microbiol. 2012;59: 134-44

13. Hornok S, de la Fuente J, Biro N. Fernandez de Mera IG, Meli ML, Elek V, et al. first molecular evidence of Anaplasma ovis and Rickettsia spp. in keds (Diptera: Hippoboscidae) of sheep and wild ruminants. Vector Borne Zoonotic Dis. 2011:11:1319-21.

14. Chu CY, Jiang BG, Qiu EC, Zhang F, Zuo SQ, Yang H, et al. Borrelia burgdorferi sensu lato in sheep keds (Melophagus ovinus), Tibet. China Vet Microbiol. 2011;149:526-9.

15. Luedke AJ, Jochim MM, Bowne JG. Preliminary bluetongue transmission with the sheep ked Melophagus ovinus (L.). Can J Comp Med Vet Sci. 1965; 29:229-31.

16. Hubalek Z, Cerny V, Mittermayer T, Kilik J, Halouzka J, Juricova Z, et al. Arbovirological survey in Silica plateau area, Roznava District, Czechoslovakia. J Hyg Epidemiol Microbiol Immunol. 1986;30:87-98.

17. Nelder MP, Lloyd JE, Loftis AD, Reeves WK. Coxiella burnetii in wild-caught filth flies. Emerg Infect Dis. 2008:14:1002-4.

18. Rudolf I, Betasova L, Bischof V, Venclikova K, Blazejova H, Mendel J, et al. Molecular survey of arthropod-borne pathogens in sheep keds (Melophagus ovinus), Central Europe. Parasitol Res. 2016;115:3679-82.

19. Degnan $\mathrm{PH}$, Ochman H. Illumina-based analysis of microbial community diversity. ISME J. 2012;6:183-94

20. Caporaso JG, Lauber CL, Walters WA, Berg-Lyons D, Huntley J, Fierer N, et al. Ultra-high-throughput microbial community analysis on the Illumina HiSeq and MiSeq platforms. ISME J. 2012;6:1621-4.

21. Ahn J, Yang L, Paster BJ, Ganly I, Morris L, Pei Z, et al. Oral microbiome profiles: $16 \mathrm{~S}$ rRNA pyrosequencing and microarray assay comparison. PLoS One. 2011:6:e22788

22. Magoč T, Salzberg SL. FLASH: fast length adjustment of short reads to improve genome assemblies. Bioinformatics. 2011;27:2957-63.

23. Caporaso JG, Kuczynski J, Stombaugh J, Bittinger K, Bushman FD, Costello EK, et al. QIIME allows analysis of high-throughput community sequencing data. Nat Methods. 2010;7:335-6. 
24. Edgar RC. UPARSE: highly accurate OTU sequences from microbial amplicon reads. Nat Methods. 2013;10:996-8.

25. Edgar RC. MUSCLE: multiple sequence alignment with high accuracy and high throughput. Nucleic Acids Res. 2004;32:1792-7.

26. Kaiser PO, Riess T, O'Rourke F, Linke D, Kempf VA. Bartonella spp.: throwing light on uncommon human infections. Int J Med Microbiol. 2011;301:7-15.

27. Breitschwerdt EB, Maggi RG, Chomel BB, Lappin MR. Bartonellosis: an emerging infectious disease of zoonotic importance to animals and human beings. J Vet Emerg Crit Care (San Antonio). 2010;20:8-30.

28. Li XL, Yin CH. Recognition of Bartonella infection. J Pathog Biol. 2012;7:872-5.

29. Angelakis E, Pulcini C, Waton J, Imbert P, Socolovschi C, Edouard S, et al. Scalp eschar and neck lymphadenopathy caused by Bartonella henselae after tick bite. Clin Infect Dis. 2010;50:549-51.

30. Novakova E, Hypsa V, Moran NA. Arsenophonus, an emerging clade of intracellular symbionts with a broad host distribution. BMC Microbiol. 2009; 9:143

31. Duron O, Bouchon D, Boutin S, Bellamy L, Zhou LQ, Engelstädter J, et al. The diversity of reproductive parasites among arthropods: Wolbachia do not walk alone. BMC Biol. 2008;6:27.

32. Gherna RL, Werren JH, Weisburg W, Cote R, Woese CR, Mandelco L, et al. Notes: Arsenophonus nasoniae gen. nov., sp. nov., the causative agent of the son-killer trait in the parasitic wasp Nasonia vitripennis. Int J Syst Bacteriol. 1991;41:563-5.

33. Kirkness EF, Haas BJ, Sun W, Braig HR, Perotti MA, Clark JM, et al. Genome sequences of the human body louse and its primary endosymbiont provide insights into the permanent parasitic lifestyle. Proc Natl Acad Sci USA. 2010; 107:12168-73.

34. O'Neill SL, Giordano R, Colbert AM, Karr TL, Robertson HM. 16S rRNA phylogenetic analysis of the bacterial endosymbionts associated with cytoplasmic incompatibility in insects. Proc Natl Acad Sci USA. 1992;89: 2699-702.

35. Juchault P, Frelon M, Bouchon D, Rigaud T. New evidences of feminizing bacteria in terrestrial isopods: evolutionary implications. C R Acad des Sci IIIVie. 1994;317:225-30

36. Bandi C, Anderson TJ, Genchi C, Blaxter ML. Phylogeny of Wolbachia in filarial nematodes. Proc Biol Sci. 1998;265:2407-13.

37. Breeuwer JA, Stouthamer R, Barns SM, Pelletier DA, Weisburg WG, Werren $J H$. Phylogeny of cytoplasmic incompatibility microorganisms in the parasitoid wasp genus Nasonia (hymenoptera: Pteromalidae) based on 165 ribosomal DNA sequences. Insect Mol Biol. 1992;1:25-36.

38. Cordaux R, Michel-Salzat A, Frelon-Raimond M, Rigaud T, Bouchon D. Evidence for a new feminizing Wolbachia strain in the isopod Armadillidium vulgare: evolutionary implications. Heredity (Edinb). 2004;93: 78-84.

39. Dong P, Wang JJ. Reproductive manipulation of Wolbachia to its hosts. Chin Bull Entomol. 2006:43:288-94.

40. Werren JH, Windsor D, Guo L. Distribution of Wolbachia among Neotropical arthropods. Proc R Soc Lond B Biol Sci. 1995;262:197-204.

41. Kose H, Karr TL. Organization of Wolbachia pipientis in the Drosophila fertilized egg and embryo revealed by an anti-Wolbachia monoclonal antibody. Mech Dev. 1995;51:275-88.

42. Dobson SL, Bourtzis K, Braig HR, Jones BF, Zhou W, Rousset F, et al. Wolbachia infections are distributed throughout insect somatic and germ line tissues. Insect Biochem Mol Biol. 1999;29:153-60.

43. Zordan $\mathrm{S}$, Prenger-Berninghoff $\mathrm{E}$, Weiss $\mathrm{R}$, van der Reijden $\mathrm{T}$, van den Broek $P$, Baljer $G$, et al. Multidrug-resistant Acinetobacter baumannii in veterinary clinics, Germany. Emerg Infect Dis. 2011;17:1751-4.

44. Peleg AY, Seifert H, Paterson DL. Acinetobacter baumannii: emergence of a successful pathogen. Clin Microbiol Rev. 2008;21:538-82.

45. Turton JF, Shah J, Ozongwu C, Pike R. Incidence of Acinetobacter species other than A. baumannii among clinical isolates of Acinetobacter: evidence for emerging species. J Clin Microbiol. 2010;48:1445-9.

46. Kempf M, Rolain JM, Diatta G, Azza S, Samb B, Mediannikov O, et al. Carbapenem resistance and Acinetobacter baumannii in Senegal: the paradigm of a common phenomenon in natural reservoirs. PLoS One. 2012; 7:e39495.

47. Kumsa B, Socolovschi C, Parola P, Rolain JM, Raoult D. Molecular detection of Acinetobacter species in lice and keds of domestic animals in Oromia regional state, Ethiopia. PLoS One. 2012;7:e52377.

\section{Submit your next manuscript to BioMed Central and we will help you at every step:}

- We accept pre-submission inquiries

- Our selector tool helps you to find the most relevant journal

- We provide round the clock customer support

- Convenient online submission

- Thorough peer review

- Inclusion in PubMed and all major indexing services

- Maximum visibility for your research

Submit your manuscript at www.biomedcentral.com/submit

) Biomed Central 